10.53116/pgaflr.2017.1.2

\title{
Tax Procedure Code in the Czech Republic
}

\author{
Marie Karfíková*, Radim Boháćc*
}

* Prof. JUDr. Maria Karfíková, CSc, Full Professor, Head of Department, Department of Financial
Law and Finances, Faculty of Law, Charles University, Prague. (e-mail: karfikov@prf.cuni.cz)
** Doc. JUDr. Radim Boháć, PhD, Associate Professor, Department of Financial Law and Finances,
Faculty of Law, Charles University, Prague. (e-mail: bohac@prf.cuni.cz)

\begin{abstract}
The paper deals with Tax Procedure Code in the Czech Republic. The aim of this paper is to describe the Czech Tax Procedure Code and to present and evaluate its significant possible change. The basic principles of the Czech Tax Procedure Code are set out and the basic structure of the Tax Procedure Code is introduced. The study concludes that the tax procedure has been successfully codified in the Czech Republic. The adoption of Tax Procedure Code is a great achievement and the result of many years of work undertaken to preserve the autonomy of the tax procedure. Then the article is focused on the considered change of Tax Procedure Code related to the principle of tax self-assessment and tax additional self-assessment. It is further concluded that every tax in the broad sense should have a clearly stated model which is applicable for its assessment. Establishing the tax self-assessment and tax additional tax-assessment regime could make the examination stage of tax administration much clearer.
\end{abstract}

Keywords: tax; tax procedure law; tax codification; tax self-assessment

\section{Introduction}

The aim of this paper $^{1}$ is to describe the Czech Tax Procedure Code which came into effect in 2011 and to present and evaluate its significant possible change. The substance of this possible change is to introduce the principles of tax self-assessment and tax self-additionalassessment.

The first part is about the recent legal regulation of tax procedure in the Czech Republic. The basic principles on which this legislation rests are set out and the basic structure of the Tax Procedure Code is introduced.

The second chapter is focused on the considered change of Tax Procedure Code. This change deals with the assessment of tax and additional assessment of tax. The tax assessment legislation is not uniform today. The general regulation in the Tax Procedure Code is supplemented by a number of special modifications in individual tax laws. The main principle of tax self-assessment and additional tax self-assessment are described and analysed. 


\section{Recent Tax Procedure Code}

Developments in the codification of financial law, i.e. tax procedure $\operatorname{law}^{2}$ culminated through the adoption of a new $\mathrm{act}^{3}$ in 2009. The new legislation contained 266 sections and came into effect on January 1, 2011, thus the requirement of vacatio legis was fulfilled. Regarding the relationship to the Administrative Procedure Code, the former legislation's principle based on the separation of the two codes has been followed. Section 262 therefore states that "The Administrative Procedure Code shall not apply in tax administration". As regards the application of the provisions of the Tax Procedure Code, the provision 4 states that "the provisions of the Tax Procedure Code shall apply unless another law on tax provides otherwise". This implies that even after the effective date of this Act, procedural provisions contained in other tax laws shall prevail before the procedural provisions of the Tax Procedure Code.

The Tax Procedure Code embodies a new comprehensive regulation of the tax procedure and compared to former legislation, contains higher amount of provisions (more than 260) with short paragraphs and sentences and is essentially organized in a systematically new way. The explanatory memorandum to this draft law stated that the aim of the new legislation was to establish a transparent and clear regulation of tax administration with emphasis on reducing the administrative burden and encouraging the use of electronic means for tax administration and communication with taxpayers. Many institutes are adopted from the Act on Administration of Taxes and Charges and the legal text also comprises some ideas from the current case law. The Tax Procedure Code has also introduced a unified terminology for other tax laws.

The Tax Procedure Code provides for procedural rules in tax administration involving regulation of the actions of tax administrators and the rights and obligations of taxpayers and third parties arising in connection with the administration of taxes. It also contains provisions concerning the rights and obligations common for special tax laws where it is assumed a minimum number of reasonable derogations from the common provisions due to differences in various types of taxes. Addressed are in particular the consequences of breach of payment. Tax administration is a term that is used in the broadest sense for administration of financial considerations. The Tax Procedure Code specifies tax administration in all of its provisions, it is therefore a procedure (activity) regulated by tax laws which involves the interaction between the tax authorities and other persons and entities involved in tax administration. This process should be directed to meet the basic objective of tax administration, i.e. correct identification and assessment of a tax duty (in the original proceedings) and also ensuring its payment (payment stage of the proceedings). In this regard, the objective of tax administration continues to develop the very meaning of taxes that is to ensure the financing of public needs, although this is not explicitly stated in the Act.

It is therefore essential to ensure the participation of individuals (tax subjects) on the costs necessary for the effective functioning of public bodies and on the provision of public services. Therefore, the main purpose is to carry out the determined payment into the public budget in a manner specified by law. However, achieving this goal shall always be realized in accordance with the law and must be based on the proper application of 
the principles of tax administration and of the procedure law. Only when respecting these conditions can the public interest be achieved. The purpose of tax administration is conceived more generally and more balanced, as the initial criterion is not the elimination of possible tax evasion, but the correct identification and assessment of a tax duty and ensuring its payment. The main activity of tax administrators lies in the initiation and conduct of proceedings (especially tax procedure), through which a tax is transformed into the income of a public budget, and further in the application of procedural steps provided by the Tax Procedure Code (as for example local inquiry, tax audit etc.). However, in tax administration other persons and entities also participate, especially third persons that significantly affect the final result and success of the realization of the state's entitlement to collect taxes.

Tax administration is based on the principle that the tax subjects carry the burden of persuasion regarding their tax duties. The taxpayers shall cooperate in determining their tax duty, in particular by stating properly the amount of tax that must be paid. The tax authority then revises this statement resulting in the acceptance of the alleged amount of tax determination and issuing a declaratory tax assessment or in a decision consisting in a change of the amount stated so that it corresponds to the tax duty specified by law.

The Tax Procedure Code is divided into titles, chapters, divisions and comprises six parts. Part One (sections 1 to 9) entitled Introductory Provisions is divided into two titles and contains the purpose of the Act and a list of elementary principles applied in tax administration. Part Two (sections 10 to 124a) entitled General Part on Tax Administration contains general provisions applicable to various proceedings within tax administration, in particular tax procedure. Part Three (sections 125 to 245) entitled Special Part on Tax Administration contains mainly special provisions on various types of proceedings, payment of taxes, tax administration and legal succession and relation to insolvency proceedings. Part Four (sections 246 to 254) entitled Consequences of Breach in Tax Administration contains a comprehensive set of sanctions, both for the breach of duties of financial character, and for the breach of duties of non-financial character. Part Five (sections 254a to 265) contains common, enabling, transitional and final provisions and Part Six (section 266) entitled Effect contains a provision on the entry into force of the Tax Procedure Code which shall be January 1, 2011.

The Tax Procedure Code is structured in a way that each phase of the tax procedure (from registration through assessment of the tax to its payment, collection and its enforcement) appears in Part Three. To these multiple stages of tax procedure, it is necessary to add explanatory definitions and general provisions in Part One and Two of the Tax Procedure Code. In case of breach of obligations arising from tax administration, it is necessary to focus on Part Four.

The process of creation of tax laws reflects, among other things, also the fact that tax law is a branch of law, which, by its nature, is subject to economic development and considerable political influences. The consequence of this influence results in remarkably numerous changes in tax laws. However, it should not be this way regarding the tax procedure law, more specifically the procedural legislation, which sets rules for the administration of taxes. 
The Tax Procedure Code as a codified tax procedure legislation that provides for transparent procedural rules in the framework of tax administration with emphasis on reducing the administrative burden and enhancing the use of electronic means in tax administration and communication with taxpayers. The adoption of the Tax Procedure Code has ensured a higher legal certainty for taxpayers and tax administrators, as it responds to the experience gained from the problems of interpretation relating to the former Act on Administration of Taxes and Charges.

This legislation constitutes a comprehensible text based on unified terminology and systemic links, which can be considered a primary requirement for any legislative text in general. The desired characteristics of a new legislation can be summarized as a long-term stability and resistance to changes in the related legislation, its universality, i.e. it is applicable to all cases of the same nature with no formal barriers to overcome unwanted fragmented legislation. This requires the wording to be general enough (instead of being casuistic), to be ready to resolve specific situations and to accommodate the application of specific terms within its structure. Only the legislation that is based on a combination of general principles (whether expressed or not) and specific rules has the potential to deal with situations that were not anticipated in advance. These general requirements meet in the Tax Procedure Code in the framework of the tax procedure because it provides a stable legal environment even in a situation where there are significant changes in substantive tax laws and in the organizational structure. This Code has proven its qualities even in an ever closer involvement of the economy and public administration into international structures which occurs in the area of taxation.

It is possible to state that in the Czech Republic the tax procedure has been successfully codified. The adoption of Tax Procedure Code is a great achievement and result of many years of work undertaken to preserve the autonomy of the tax procedure. ${ }^{4}$

\section{Considered Change of Tax Procedure Code}

There is an emerging tendency in relation to the suggested amendment to the Tax Procedure Code to speak about a tax self-assessment and an additional tax self-assessment (together also sometimes called "tax self-determination"), which should replace or enhance the current general regime of a tax assessment under the Tax Procedure Code. A project called "tax self-assessment" is currently being conducted by the Ministry of Finance, which focuses on both topics mentioned above. This project's realization is one of the Ministry of Finance's ${ }^{5}$ priorities, and this priority exceeds the current election period because it is a long-term project. $^{6}$

The general regime of the tax assessment is stated in Title IV of Part Three of the Tax Procedure Code which is called "Examination procedure". The substance of an examination procedure is a correct tax assessment, i.e. its assessment and additional assessment. The tax shall be assessed on the basis of a tax return, tax report or ex officio according to Section 139, Par. 1 of the Tax Procedure Code. Nevertheless, this general provision is not applicable to all payments that are recognised as taxes under the Tax Procedure Code, but it applies only to payments that also bring the duty to submit a tax return. 
It is in the nature of things that this general provision cannot be applied to payments that are administered in a form of divided administration, because there is no examination stage. These payments are regulated only by provisions concerning the payment stage, because there is no examination stage for this type of payments, e.g. fines imposed during an administrative procedure.

Furthermore, a number of different payments (or considerations) exist that are not subjects to submitting the tax return, and a tax administrator does not determine the value of a tax duty. These payments (e.g. some administrative fees) are only paid and no formal act is conducted (e.g. issuing a decision) by a tax administrator. The value of such payments (in most cases) is stipulated by a statute or a calculation of its value, and is not complex. Some of these considerations are assessed by a tax administrator if the payment is not completed during a set period of time (e.g. municipal fees). Finally, it is necessary to add that it has already been possible to find a solution in the legal order taxes, which are administered using the tax self-assessment and additional self-assessment. Specifically, they are value added taxes in a one-stop shop regime and gambling tax. ${ }^{7}$

It can be concluded that the legal regulation of tax assessment is not uniformed. Even though there is one general legal regime for tax assessment, this regime is not applicable for all taxes (and fees) and there are different tax assessment regimes (or provisions under which no tax assessment is conducted at all).

Taxes in the broad sense may be divided into: taxes assessed by a tax administrator based on a submitted tax return or ex officio; taxes self-assessed and additionally selfassessed based on a submitted tax return or an additional tax return; taxes that are only paid and a tax administrator assesses them in case they are not paid in time; taxes that are only paid and a tax administrator never assesses them and payments, administered through divided administration that are imposed during an administrative procedure or other procedure and/or are assessed without further action based on provisions of the law.

It is obvious that different regimes of tax assessment exist but the general regime is only the regime stipulated in the Tax Procedure Code, which is the tax assessment by a tax administrator based on a submitted tax return or assessed ex officio. It is a question whether there should exist more different general regimes. We think it should be so because the general legal regulation should explicitly cover every basic form of the tax assessment. This should be one of the goals of the self-assessment project.

Essentially, the tax self-assessment and the additional tax self-assessment regime is a tax assessment without further action (ex lege) based on a submitted (eventually not submitted) tax return or based on a carried out (eventually not carried out) identified payment.

While in the general tax assessment regime under the Tax Procedure Code based on the submitted tax return there is the tax assessment by a decision issued by a tax administrator (i.e. payment assessment, additional payment assessment, eventually collective prescriptive list), there is no payment assessment or additional payment assessment issued by a tax administrator in the tax self-assessment and self-additional assessment regime and a tax is assessed independently based on legal rules (therefore the name self-assessment and self-additional assessment). 
The tax self-assessment and tax self-additional assessment regime based on tax return (regardless whether in a form of acts of commission or omission) means that the tax is:

- self-assessed based on a submitted or not submitted regular tax return,

- additionally self-assessed based on a submitted additional tax return,

- additionally assessed ex officio by a tax administrator based on a tax investigation (esp. tax control).

A declared goal of the tax self-assessment and additional self-assessment is to lower the tax administrator's administrative burden, because a tax administrator will not be forced to issue payment assessments or additional payment assessments that are only filed and tax payers are not notified. ${ }^{8}$

For tax subjects the regime of tax self-assessment and tax additional self-assessment may in relation to taxes with returnable tax deductions (e.g. excessive deduction under value added tax) bring an advantage. When a tax subject submits regular or additional tax return in which he/she will state a tax deduction, the tax deduction in the stated amount will be self-assessed or additionally self-assessed after a period stated by a statute. In relation to this, a legal regulation is considered that would allow a tax administrator to withhold only a disputed part of such tax deduction. Nowadays, a tax administrator withholds a whole tax deduction even though only a part of the tax deduction is disputed. This leads to a situation where the tax subject cannot deal with money that rightfully belongs to him/ her. This situation is unsustainable and it is necessary to change it.

A further undisputable advantage of tax self-assessment and additional self-assessment regime is that a tax subject will know what his/her last tax duty was. In a general regime under the Tax Procedure Code the tax subject in most cases does not know whether a tax administrator has assessed his/her tax duty based on a submitted tax return. A tax subject therefore does not know what his/her last tax duty was and it is unclear for him/her whether an additional tax return will lead to an additional tax assessment or whether it will serve only as a basis for tax assessment.

As stated above, taxes in the broad sense can be, based on the form of their examination stage, divided into:

a) taxes that are assessed by a tax administrator based on a submitted tax return or ex officio,

b) taxes that are self-assessed or additionally self-assessed based on a submitted tax return, eventually on an additionally submitted tax return,

c) taxes that are only paid and a tax administrator assesses them in a case that they are not paid in time,

d) taxes that are only paid and a tax administrator never assesses them,

e) financial considerations that are administered through a divided administration regime which are imposed during an administrative procedure or in a different procedure and/or they are imposed without any formal act (ex lege).

Taxes referred to in point a) would be assessed as nowadays. It is a recent general regime of the tax assessment under the Tax Procedure Code. In such a case tax would be assessed on 
the basis of a submitted tax return or ex officio. Moreover, additional tax assessment would be done on the basis of a submitted additional tax return or ex officio.

We believe that a model referred to in point a) could be supplemented by a model described under point b) if there was not the tax subject's duty to submit a tax return but tax would be assessed, eventually additionally assessed ex officio by a tax administrator. This model could be used in cases when the tax administrator has enough information necessary for tax assessment so that it is not necessary to have a tax subject submit a tax return but with a complicated calculation the tax administrator has to calculate the value of a tax duty and to assess such a tax.

Models described under points c) and d) are models that use self-assessment and additional self-assessment of tax. Either based on a tax return or based on a payment. The self-assessment and self-additional assessment of tax based on a tax return [letter c)] are currently used in the legal order for value added tax and for gambling tax. The tax selfassessment and additional self-assessment based on a payment [letter d)] would be explicitly stated and it would be used for various taxes in the broad sense which already use this model. Examples of this are especially administrative and municipal fees but also other fees sui generis (e.g. fees in atomic act).

For pecuniary considerations administered through a divided administration, a current legal regulation would still exist. These considerations are imposed during an administrative procedure or other procedure, eventually they stem directly from the law. Therefore, the tax assessment regime under the Tax Procedure Code is not applicable for these considerations.

Every tax in the broad sense should have a clearly stated model which is applicable for its assessment. Establishing the tax self-assessment and tax additional tax-assessment regime could make the examination stage of tax administration much clearer.

\section{Conclusion}

The aim of this paper was to describe the Czech Tax Procedure Code and to present and evaluate its possible significant change.

First and foremost, according to recent legal regulation of tax procedure in the Czech Republic, the basic principles of the Czech Tax Procedure Code were set out and the basic structure of the Tax Procedure Code was introduced. It was concluded that the tax procedure has been successfully codified in the Czech Republic. The adoption of the Tax Procedure Code is a great achievement and the result of many years of work undertaken to preserve the autonomy of the tax procedure. The second chapter was focused on the considered change of the Tax Procedure Code. The substance of this possible change is to introduce and analyse the principle of tax self-assessment and tax additional self-assessment. Benefits resulting from these new principles were presented.

As a conclusion, it can be stated, that every tax in the broad sense should have had a clearly stated model which is applicable for its assessment. Establishing the tax selfassessment and tax additional tax-assessment regime could make the examination stage of the tax administration much clearer. 


\section{References}

1. This paper has been elaborated within the programme "PROGRES Q02 - Publicization of Law in the European and International Context" which is realized in 2017 at the Faculty of Law of Charles University.

2. Milan Bakeš, Marie Karfíková, Petr Kotáb \& Hana Marková (eds.), Finanční právo. 6. Upravené vydání. [Financial Law. 6th Edited Issue], 255 (Praha, C. H. Beck, 2012).

3. Act no. 280/2009 Coll., Tax Procedure Code.

4. Alena Kohoutková, Co zuistal dañový yád dlužen? [What the Tax Code Still Owes] (Systém ASPI - ASPI ID LIT34542CZ, Wolters Kluwer, 2017) (accessed 19 August 2017).

5. Ministerstvo financi predstavilo své úspěchy a plány. [The Ministry Introduced Its Successes and Plans], http://mfcr.cz/cs/aktualne/v-mediich/2016/mf-predstavilo-sve-uspechy-a-plany-24535 (accessed 19 August 2017).

6. Alena Schillerová o prioritách a plánech v oblasti danè. [Alena Schollerová About the Priorities and Plans on the Field of Taxes], http://mfcr.cz/cs/aktualne/v-mediich/2016/alena-schillerova-o-prioritach-aplanech-23809 (accessed 19 August 2017).

7. See Act No. 187/2016 Coll., On Gambling Tax, as amended by Act No. 298/2016 Coll.

8. Vládni náurh zákona o dani $\mathrm{z}$ hazardnich her [Government Draft Regulation on Gambling Tax], 53, http:// psp.cz/doc/00/11/55/00115509.pdf (accessed 19 August 2017). 